\title{
TANTANGAN LEMBAGA PENDIDIKAN ISLAM SEBAGAI BENTENG PERTAHANAN MORAL BANGSA
}

\author{
Ramli Rasyid \\ Pascasarjana UIN Alauddin Makassar \\ Jalan Sultan Alauddin Nomor 63 Makassar \\ mail: ramli1977@yahoo.co.id
}

\begin{abstract}
Abstrak:
Sejumlah masalah yang dihadapi oleh lembaga pendidikan tampak sangat kompleks, di antaranya belum maksimalnya mutu pada semua jenjang pendidikan. Peningkatan kualitas lembaga pendidikan Islam merupakan sesuatu yang mutlak harus dilakukan karena merupakan bagian dari sistem pendidikan nasional. Peningkatan mutu lembaga itu bertujuan memberi jaminan kepada masyarakat, yakni suatu jaminan bahwa penyelenggaraan pendidikan itu sesuai dengan apa yang seharusnya terjadi dan diharapkan masyarakat. Berdasarkan karakteristiknya, institusi pendidikan Islam tidak hanya mencetak figur intelektual yang potensial, melainkan juga mencetak figur yang berkarakter dan beretika. Perhatian utama dari institusi pendidikan Islam adalah meningkatkan kualitas jasmani dan rohani.
\end{abstract}

\begin{abstract}
:
The problems faced by educational institutions are more complicated. One of them is the quality of all the level education have not increased. The increasing quality of islamic educational institutions is something absolut because it is a part of educational national system. The increasing quality of the institutions have a purpose to give a guarantee to the people, a guarantee that the implementation of the education appropriates with what must be happen and wished by the people. Based on its characteristic, islamic educational institutions not only create the potential intelectually figure (intelectual oriented), but also create the character and ethical figure. The main concern of the islamic educational institution is the improvement of both body and spirit.
\end{abstract}

Kata Kunci:

Pembaruan, Pendidikan Islam, Globalisasi, Moral

SEJAK manusia menginginkan kemajuan dalam kehidupan, maka sejak itu muncul gagasan untuk mengadakan pewarisan, pelestarian dan pengembangan kebudayaan melalui pendidikan. Oleh karena itu, dalam sejarah kehidupan umat manusia pendidikan senantiasa menjadi perhatian utama dalam rangka memajukan kehidupan generasi agar senantiasa sejalan dengan tuntutan dan kemajuan masyarakat.

Mendidik generasi adalah merencanakan apa dan bagaimana bentuk generasi mendatang serta disesuaikan dengan kebutuhan zaman. Generasi bangsa diproses dalam dunia pendidikan yang meliputi pembentukan karakter, pengembangan potensi, dan eksplorasi sumber daya manusia.

Berbicara tentang pendidikan Islam, maka orientasi pendidikan Islam tidak hanya menekankan pada aspek kognitif, tetapi juga aspek pengisian jiwa, pembinaan 
akhlak, dan kepatuhan dalam menjalankan ibadah kepada Allah swt. Selain itu, harus dipikirkan berbagai upaya menciptakan generasi muda muslim yang kreatif, inovatif, produktif, dan mandiri sehingga mempunyai ketegaran yang kokoh dalam menghadapi berbagai tantangan.

Di era milenium ketiga, di saat dunia semakin tidak berjarak dan mengglobal, transformasi budaya dan arus informasi yang sulit dibendung telah memberikan andil besar dalam proses terjadinya dekadensi moral, khususnya di kalangan anakanak dan remaja. Budaya kekerasan dan pornografi telah masuk ke dalam ruang keluarga melalui media cetak dan elektronik.

Lembaga-lembaga pendidikan secara umum banyak yang tidak berdaya dengan serbuan arus globalisasi dan transformasi sosial budaya tersebut. Sebagai akibatnya, lahirlah generasi-generasi yang berilmu tetapi tidak bermoral. Di sinilah lembaga pendidikan Islam (pesantren, madrasah, dan perguruan tinggi Islam) harus mengambil peran yang besar dalam upaya menghasilkan generasi yang berilmu dan bermoral.

Lembaga pendidikan Islam merupakan lembaga pendidikan yang menawarkan ide pentingnya menjaga moralitas untuk membentuk sebuah tatanan masyarakat yang kuat. Dengan dasar bangunan moral yang kuat, tentu saja bangsa ini bisa melakukan proses seleksi dan filter terhadap segala macam kebudayaan baru yang masuk sebagai efek perkembangan, keterbukaan, dan kemajuan teknologi informasi yang begitu luar biasa saat ini. Lembaga pendidikan Islam merupakan benteng moral terkokoh yang dimiliki bangsa Indonesia dalam menghadapi arus serangan globalisasi, teknologi, dan informasi. Kenyataan ini tak bisa dipungkiri oleh siapapun.

Tulisan ini berusaha membahas gambaran umum lembaga pendidikan Islam di Indonesia, urgensi lembaga pendidikan Islam sebagai benteng pertahanan moral bangsa, dan tantangan lembaga pendidikan Islam sebagai benteng pertahanan moral bangsa.

\section{LEMBAGA PENDIDIKAN ISLAM DI INDONESIA}

Perjalanan sejarah pendidikan Islam di Indonesia hingga sekarang telah melalui tiga periode. Pertama, priode awal sejak kedatangan Islam yang ditandai dengan pendidikan Islam yang terkonsentrasi di pesantren, dayah, dan surau atau masjid. Kedua, periode ketika pendidikan Islam telah dimasuki oleh ide-ide pembaruan pemikiran Islam pada awal abad ke-20. Periode ini ditandai dengan lahirnya madrasah yang telah memasukkan pelajaran umum ke dalam program kurikulumnya. Ketiga, periode lahirnya perguruan tinggi Islam dan pendidikan Islam telah terintegrasi ke dalam sistem pendidikan nasional. ${ }^{1}$

Lembaga-lembaga pendidikan Islam tersebut tidaklah tumbuh dengan serta merta, tetapi melalui proses sebagaimana yang terjadi pada lembaga lainnya. Terdapat tiga model lembaga pendidikan Islam di Indonesia yang selama ini memiliki andil dalam proses pembentukan peserta didik yang berilmu dan bermoral sekaligus yaitu pesantren, madrasah, dan perguruan tinggi Islam. 


\section{Pesantren}

Ada beberapa istilah yang ditemukan dan sering digunakan untuk menunjuk jenis pendidikan Islam tradisional khas Indonesia. Di Jawa, termasuk Sunda dan Madura, umumnya dipergunakan istilah pesantren atau pondok. Di Aceh, dikenal dengan istilah dayah atau rangkung atau meunasah, sedangkan di Minangkabau disebut surau. ${ }^{2}$

Pesantren menurut pengertian dasarnya adalah "tempat belajar para santri", sedangkan pondok berarti "rumah atau tempat tinggal sederhana yang terbuat dari bambu". Di samping itu, "pondok" juga berasal dari bahasa Arab "funduk" yang berarti "hotel atau asrama". 3

Pengertian lain adalah istilah pesantren berasal dari bahasa Sansekerta yang memperoleh wujud dan pengertian tersendiri dalam bahasa Indonesia. Asal kata san berarti orang baik (laki-laki) disambung tra berarti suka menolong, santra berarti orang baik-baik yang suka menolong. Pesantren berarti tempat untuk membina manusia menjadi orang baik. ${ }^{4}$ Sedangkan Nurcholish Madjid berpendapat bahwa kata santri berasal dari bahasa Jawa, cantrik yang berarti orang yang selalu mengikuti guru kemana guru pergi menetap dengan tujuan dapat belajar dari guru mengenai sesuatu keahlian. ${ }^{5}$

Adapun pengertian secara terminologi dapat dikemukakan beberapa pendapat yang mengarah pada definisi pesantren. Abdurrahman Mas'ud menulis,

The word pesantren stems from "santri" which means one who seeks Islamic knowledge. Usually the word pesantren refers to a place where the santri devotes most of his or her time to live in and acquire knowledge. 6

Pesantren adalah lembaga pendidikan Islam tertua yang merupakan produk kearifan lokal Indonesia. Pesantren senantiasa menjadi sumber inspirasi yang tidak pernah kering bagi para pecinta ilmu dan peneliti yang berupaya mengurai anatominya dari berbagai dimensi. Sebagai lembaga pendidikan yang telah lama berakar di negeri ini, pesantren diakui memiliki andil yang sangat besar terhadap perjalanan sejarah bangsa. Pesantren tidak hanya melahirkan tokoh-tokoh nasional yang paling berpengaruh di negeri ini, tetapi juga diakui telah berhasil membentuk watak tersendiri, di mana bangsa Indonesia yang mayoritas beragama Islam selama ini dikenal sebagai bangsa yang akomodatif dan penuh tenggang rasa.

Pesantren merupakan lembaga pendidikan yang unik. Tidak saja karena keberadaannya yang sudah sangat lama, tetapi juga karena kultur, metode, dan kesederhanaan yang diterapkan oleh lembaga agama tersebut. Kesederhanaan pesantren dahulu sangat terlihat, baik segi fisik bangunan, metode, bahan kajian maupun perangkat belajar lainnya. Hal itu dilatarbelakangi kondisi masyarakat dan ekonomi yang ada pada waktu itu. ${ }^{7}$

Ciri khas lain dari lembaga ini adalah rasa keikhlasan yang dimiliki para santri dan sang kiai. Hubungan mereka tidak hanya sekedar sebagai murid dan guru, tapi lebih seperti anak dan orang tua. Tidak heran bila santri merasa betah tinggal di pesantren walaupun dengan segala kesederhanaannya. ${ }^{8}$ 
Sepanjang sejarah, pesantren terus menekuni bidang pendidikan dan menjadikannya sebagai fokus kegiatan pesantren. Dalam mengembangkan pendidikan, pesantren telah menunjukkan daya tahan yang cukup kokoh sehingga mampu melewati berbagai zaman dengan beragam masalah yang dihadapinya. Dalam sejarahnya itu pula, pesantren telah menyumbangkan sesuatu yang tidak kecil bagi pendidikan Islam di negeri ini.

\section{Madrasah}

Kata madrasah berasal dari bahasa Arab. Kata dasar madrasah adalah درس yang berarti belajar. Madrasah kemudian lazim diartikan tempat belajar. ${ }^{9}$ Padanan madrasah dalam bahasa Indonesia adalah sekolah, lebih dikhususkan lagi sekolahsekolah agama Islam. Dari sini dapat dipahami bahwa madrasah adalah suatu lembaga yang mengajarkan ilmu-ilmu keislaman. Perkataan madrasah di tanah Arab ditujukan untuk semua sekolah secara umum. Di Indonesia ditujukan buat sekolah-sekolah yang mempelajari ajaran-ajaran Islam secara lebih mendetail. ${ }^{10}$

Pertumbuhan madrasah dilatarbelakangi oleh dua faktor. Pertama, faktor pembaruan Islam. Terbentuknya madrasah tidak lepas dari gerakan pembaruan Islam yang dimulai oleh santri-santri yang pernah belajar di Timur Tengah. Kedua, respons terhadap politik pendidikan pemerintah Belanda. Sekolah yang didirikan oleh pemerintah Belanda sebagai alat politik penguasa dan sifatnya diskriminatif serta dikelolah secara modern, membuat kalangan intelektual muslim berusaha untuk merekonstruksi pendidikan Islam yang lebih maju. ${ }^{11}$

Madrasah telah mengalami perkembangan jenjang dan jenisnya searah dengan perkembangan bangsa Indonesia. Perkembangan tersebut telah mengubah pendidikan dari bentuk awal seperti pengajian di rumah-rumah, musala dan masjid menjadi lembaga formal sekolah, seperti madrasah yang dikenal sekarang ini.

\section{Perguruan Tinggi Islam}

Respons umat Islam terhadap penyelenggaraan pendidikan Islam tidak terbatas pada pesantren, madrasah, atau sekolah, tetapi juga sampai pada penyelenggaraan pendidikan tinggi. Lembaga pendidikan tinggi Islam, mempunyai kontribusi terhadap pengembangan pendidikan di Indonesia sebagai bagian dari sistem pendidikan nasional. Pengembangan studi keislaman yang ada di perguruan tinggi Islam juga telah banyak memberikan kontribusi dalam mencerdaskan bangsa Indonesia.

Pendirian lembaga pendidikan tinggi Islam diawali dengan pendirian Sekolah Tinggi Islam (STI) pada bulan Juli 1945. Dalam pergolakan setelah proklamasi kemerdekaan, ibu kota Republik Indonesia terpaksa pindah ke Yogyakarta, maka STI ikut dipindahkan ke kota tersebut pada tahun 1946. Selanjutnya, pada tanggal 22 Maret 1946, nama STI diubah menjadi Universitas Islam Indonesia dengan empat fakultas; agama, pendidikan, hukum, dan ekonomi. Selanjutnya, Fakultas Agama UII berubah menjadi Perguruan Tinggi Agama Islam Negeri (PTAIN). ${ }^{12}$

Pada awalnya, konsentrasi kelimuan di IAIN/STAIN adalah pengembangan ilmu-ilmu agama. Menyikapi globalisasi dengan tuntutan yang semakin berkembang 
serta cita-cita untuk mengintegrasikan ilmu yang tergolong perennial knowledge dan ilmu yang tergolong acquired knowledge, maka muncullah ide untuk mengembangkan lagi IAIN menjadi universitas. Ide ini akhirnya melahirkan Universitas Islam Negeri (UIN).

Perkembangan selanjutnya, dunia perguruan tinggi Islam di Indonesia khususnya IAIN dan STAIN, menggeliat untuk menyesuaikan diri dengan perkembangan yang terjadi secara lokal ataupun global. Wujudnya adalah memperluas kewenangan yang telah dimilikinya selama ini yang kemudian disebut dengan program "wider mandate" (mandat yang diperluas) serta melakukan transformasi atau perubahan dari IAIN/STAIN menjadi Universitas Islam Negeri (UIN). ${ }^{13}$

Menurut Azyumardi Azra, dilihat dari perspektif perkembangan nasional dan global, maka konsep paradigma baru bagi Perguruan Tinggi Islam di Indonesia sudah merupakan sebuah keharusan. Hal ini akan mendukung eksistensi Perguruan Tinggi Islam (UIN, IAIN, STAIN) di masa yang akan datang. ${ }^{14}$

Perubahan IAIN menjadi UIN dan perubahan STAIN menjadi IAIN/UIN diharapkan mampu memberi peluang bagi rekonstruksi atau reintegrasi bangunan keilmuan, yang menjembatani ilmu-ilmu agama dan umum yang selama ini dipandang secara dikotomis. Dengan demikian, lulusan UIN, IAIN, dan STAIN mampu bersaing dengan perguruan tinggi umum lainnya. Selain itu, para alumninya adalah orang-orang yang memiliki ilmu pengetahuan yang berguna bagi dirinya dan masyarakat.

\section{URGENSI LEMBAGA PENDIDIKAN ISLAM SEBAGAI BENTENG PERTAHAN- AN MORAL BANGSA}

Abad ke-21 merupakan abad kejayaan sains dan teknologi yang mendominasi kehidupan manusia dengan begitu kuat. Melalui pencapaiannya yang luar biasa, bahkan dalam beberapa hal sangat spektakuler, sains dan teknologi dipuja laksana Tuhan. Kepatuhan manusia, khususnya di Barat, terhadap sains dan teknologi demikian tinggi, setinggi kepatuhan pemeluk agama pada keyakinannya. Hal itu karena sains dan teknologi telah memberikan manfaat yang begitu besar kepada manusia.

Hegemonisasi Barat dalam bidang sains-teknologi, menurut Azyumardi Azra, telah memunculkan globalisasi "kotak segi empat" yang bernama televisi. Benda ini sebagai produk kemajuan sains-teknologi telah melahirkan sesuatu yang tidak saja bebas nilai, tetapi juga muatan yang dibawanya tak diragukan lagi sarat dengan nilainilai tertentu. ${ }^{15}$

Akibat hal tersebut, kini anak bangsa terkesan kehilangan jati dirinya. Pagi hari, seseorang disanjung sebagai pahlawan, dan sore hari dikutuk sebagai penjahat. Antara koruptor dan penderma dapat bertemu dalam pribadi yang sama. Berbagai sikap mendua telah menjadi perilaku nyata dan lumrah dalam kehidupan sehari-hari. Iman sebagai penopang perilaku semakin terpenjara dalam hati, tidak bisa teraktualisasi dalam kehidupan nyata. Apa jadinya sebuah bangsa jika tak memiliki moral baik? Sementara sistem pendidikan di Indonesia (formal) terlihat lebih mementing- 
kan kualitas pemikiran daripada kualitas moral. Porsi untuk pendidikan moral jelas sekali sangat tidak berimbang.

Realitas empirik tersebut, lembaga pendidikan Islam (pesantren, madrasah, dan perguruan tinggi Islam) dengan tangan-tangan kreatif yang dilandasi norma-norma ilahi, dituntut untuk merekonstruksi pemikiran dan usaha nyata dalam membina, membimbing, dan mendidik pesrta didik agar mempunyai "identitas" yang jelas dan pribadi-pribadi yang tangguh. Pribadi yang mempunyai akhlak terhadap Tuhan, akhlak terhadap sesama manusia, dan akhlak terhadap alam. Artinya, peran lembaga pendidikan Islam adalah pelaksana operasional dalam menjalankan fungsi pendidikan Islam. Dengan demikian, misi lembaga pendidikan Islam harus sejalan dengan tujuan pendidikan Islam yakni membentuk manusia beradab yaitu manusia yang sadar atas hak dan kewajiban kepada Allah swt., atas dirinya, dan atas lingkungannya.

Sebagai bagian dari sistem pendidikan nasional, lembaga pendidikan Islam tidak hanya dituntut untuk dapat menyelenggarakan pendidikan dasar, menengah, dan tinggi yang berciri khas keagamaan, tetapi lebih jauh lembaga pendidikan Islam dituntut pula memainkan peran sebagai benteng tangguh yang akan menjaga dan memperkukuh etika dan moral bangsa. Dalam era ilmu pengetahuan dan teknologi, agama sangat relevan bagi kehidupan manusia. Agama menawarkan nilai-nilai yang dapat menciptakan keseimbangan sosial dan mengeliminasi segala bentuk permusuhan, kebencian, kekerasan, dan eksploitasi manusia. Pentingnya agama di abad ke-21 menjadi kekuatan bagi lembaga pendidikan Islam untuk lebih berkembang. Jiwa lembaga pendidikan Islam sebagai benteng moral pertahanan moral bangsa Indonesia sangat relevan dengan visi pengembangan pendidikan nasional, yaitu mewujudkan manusia Indonesia yang takwa dan produktif.

Melihat hakikat lembaga pendidikan Islam yang mencoba mengintegrasikan ilmu agama dan ilmu pengetahuan, maka lembaga pendidikan Islam, telah memainkan peran sebagai berikut:

\section{Media Sosialisasi Nilai-nilai Ajaran Agama}

Lembaga pendidikan Islam mempunyai peluang yang lebih besar untuk berfungsi sebagai media sosialisasi nilai-nilai ajaran agama kepada peserta didik secara lebih efektif karena diberikan sejak dini. Sifat keagamaan yang melekat pada kelembagaannya menjadikan lembaga pendidikan Islam mempunyai mandat yang kuat untuk melakukan peran tersebut. ${ }^{16}$

\section{Pemelihara Tradisi Keagamaan}

Salah satu peran penting yang diemban lembaga pendidikan Islam adalah memelihara tradisi-tradisi keagamaan. Pemeliharaan tradisi keagamaan ini dilakukan di samping secara formal melalui pengajaran ilmu-ilmu agama, juga dilakukan secara informal melalui pembiasaan untuk mengerjakan dan mengamalkan syariat agama sejak dini. ${ }^{17}$ 


\section{Membentuk Akhlak dan Kepribadian}

Tujuan pendidikan di lembaga pendidikan Islam tidak semata-mata untuk memperkaya pikiran peserta didik dengan pengetahuan-pengetahuan, tetapi untuk meninggikan moral, melatih dan mempertinggi semangat, menghargai nilai-nilai spiritual dan kemanusiaan, mengajarkan sikap dan tingkah laku jujur dan bermoral, serta menyiapkan para peserta didik untuk hidup sederhana dan bersih hati. ${ }^{18}$

\section{Lembaga Pendidikan Alternatif}

Konsentrasi pembangunan yang fokus di bidang material dewasa ini telah melahirkan kehidupan yang timpang. Di satu sisi berkelebihan dalam hal materi, tetapi di sisi lain merasa kosong secara mental spiritual. Di sinilah lembaga pendidikan Islam menjadi pendidikan alternatif, yakni yang menyeimbangkan antara pengetahuan umum dan agama. ${ }^{19}$

\section{Benteng Moralitas Bangsa}

Fenomena berkembangnya pembunuhan, perampokan sadis, meningkatnya kenakalan remaja, berkembangnya pergaulan bebas dan praktek prostitusi, merosotnya kepedulian sosial masyarakat, menyebabkan masyarakat mulai melirik kembali kepada lembaga pendidikan Islam seperti madrasah, pondok pesantren dan perguruan tinggi Islam untuk menyekolahkan putra-puri mereka. ${ }^{20}$

Kesadaran akan urgensi lembaga pendidikan Islam sebagai model pendidikan moralitas bangsa yang kian kering di era modern ini sekaligus benteng pembentukan karakter generasi masa depan, sudah seharusnya ini menjadi agenda strategis dalam konsep pendidikan bangsa ini. Hal itu dilakukan dengan memposisikan lembaga pendidikan Islam sejajar dengan model pendidikan umum.

Respon terhadap hal tersebut, lembaga pendidikan Islam harus meningkatkan mutu pendidikannya agar dilirik oleh masyarakat sebagai model pendidikan utama dan bukan lagi model pendidikan kelas dua. Untuk meningkatkan mutu lembaga pendidikan Islam perlu dilakukan pemberdayaan untuk menyediakan sistem pendidikan bermutu kepada masyarakat yang harus ditunjang oleh tiga apek, yaitu manajemen yang rapi, tenaga pendidik yang profesional, serta dana dan fasilitas pendidikan yang memadai. ${ }^{21}$

Lembaga pendidikan Islam yang dikelola dengan tertib dan rapi akan memiliki kesempatan besar untuk menjadi sebuah lembaga pendidikan yang berkualitas. Jika tiga apek tersebut dimiliki oleh lembaga pendidikan Islam, lembaga pendidikan Islam akan dapat mencapai standar atau patokan yang dijadikan pagu, yaitu standar nasional pendidikan.

Lembaga pendidikan Islam seperti pesantren adalah salah satu elemen terpenting dari arsitektur pendidikan nasional Indonesia. Pesantren, sebagai sampel institusi pendidikan yang mengemas dua lingkup pendidikan formal dan non-formal dalam satu durasi kurikulum full-time, terbukti telah sangat kontributif terhadap pengembangan pendidikan Indonesia, dan bahkan, juga terhadap pengembangan 
idealisme pendidikan nasional. ${ }^{22}$

Eksistensi dan kontribusi pesantren telah mengakar kuat dalam sejarah pendidikan dan pembangunan Indonesia. Di ranah pendidikan, pesantren memiliki identitas khas selaku key player yang concern dalam mencetak generasi bermoral-baik, sesuai dengan tuntutan ideal sila pertama Pancasila. Sementara di ranah sosial-masyarakat, para alumni pesantren tidak bisa juga dinafikan peran multi-sektornya terhadap pembangunan bangsa.

Madrasah merupakan salah satu lembaga pendidikan Islam terpenting di Indonesia dalam menciptakan kader-kader bangsa yang berwawasan keislaman. Salah satu kelebihan yang dimiliki madrasah adalah adanya integrasi ilmu umum dan ilmu agama. Madrasah juga merupakan bagian penting dari lembaga pendidikan nasional di Indonesia. Peranannya begitu besar dalam menghasilkan generasi penerus bangsa yang bermoral. Dalam sejarah perkembangannya, madrasah yang tadinya hanya dipandang sebelah mata, secara perlahan-lahan telah berhasil mendapat perhatian dari masyarakat. Apresiasi ini menjadi modal besar bagi madrasah untuk memberikan yang terbaik bagi bangsa.

Demikian halnya dengan perguruan tinggi Islam (UIN, IAIN, STAIN, dan PTAIS) sebagai lembaga pendidikan tinggi Islam, mempunyai kontribusi terhadap pengembangan pendidikan di Indonesia sebagai bagian dari sistem pendidikan nasional. Pengembangan studi keislaman yang dikembangkan di perguruan tinggi Islam juga telah banyak memberikan kontribusi dalam mencerdaskan bangsa Indonesia dan menjaga moralitas alumninya.

\section{TANTANGAN LEMBAGA PENDIDIKAN ISLAM SEBAGAI BENTENG PERTA- HANAN MORAL BANGSA}

Salah satu permasalahan pendidikan yang dihadapi lembaga pendidikan Islam adalah belum maksimalnya mutu pendidikan pada jenjang dasar dan menengah. Peningkatan kualitas lembaga pendidikan Islam merupakan sesuatu yang mutlak harus dilakukan karena merupakan bagian dari sistem pendidikan nasional. Peningkatan mutu lembaga pendidikan Islam bertujuan untuk memberikan suatu jaminan mutu kepada pihak-pihak yang berkepentingan atau masyarakat, yakni suatu jaminan bahwa penyelenggaraan pendidikan di lembaga pendidikan Islam itu sesuai dengan apa yang seharusnya terjadi dan sesuai dengan harapan masyarakat. ${ }^{23}$ Oleh karena itu, diharapkan lembaga pendidikan Islam mampu melaksanakan proses pelayanan pendidikan yang bermutu untuk menghasilkan output yang memiliki kompetensi yang berdaya saing secara nasional bahkan di tingkat global.

Seiring dengan perubahan zaman, lembaga pendidikan Islam kini harus berbenah diri dalam mempersiapkan generasi muslim masa depan yang kompetitif. Generasi baru Islam yang memiliki spiritual yang kokoh, berakhlak mulia, profesional, dan memiliki wawasan keilmuan yang luas, serta memenuhi standar kebutuhan lapangan kerja.

Malik Fadjar mengemukakan bahwa untuk merespons tantangan perubahan 
tersebut, maka pendidikan Islam harus dikelola menurut manajemen modern dan futuristik, yaitu suatu manajemen yang berpotensi membangun manusia profesionalintelektual dan skilled agar mereka mampu bergaul di engah-tengah komunitas global secara dinamis, kreatif, dan inovatif tanpa kehilangan jati diri sebagai muslim. ${ }^{24}$

Salah satu tantangan lembaga pendidikan Islam adalah perubahan orientasi. Perubahan orientasi pendidikan Islam sudah menjadi keniscayaan dan tuntutan zaman, terlebih di era globalisasi dewasa ini. Orientasi dari sekedar mendidik mereka untuk memahami ilmu (pengetahuan) agama haruslah diubah menjadi paham terhadap ilmu agama sekaligus ilmu sosial, ilmu humaniora, dan ilmu alam. Ilmu agama dan ilmu duniawi harus konvergen.

Lembaga pendidikan Islam selama ini kerap dianggap sebagai aktivitas pembelajaran yang hanya mengurusi masalah-masalah ritual. Sementara kajian di bidang ekonomi, politik, sosial, budaya, manajemen, kesehatan, pertanian, kelautan, dan sebagainya kurang menjadi perhatian serius. Pemisahan ilmu dalam penyelenggaraan pendidikan Islam semacam itu pada gilirannya akan menghambat kemajuan peradaban umat Islam itu sendiri.

Selain adanya pemisahan ilmu agama dari kebutuhan riil masyarakat modern, pendidikan Islam hingga kini seolah dalam posisi problematik. Di satu sisi, umat Islam berada pada romantisme historis karena pernah memiliki para pemikir dan ilmuwan besar serta memiliki kontribusi yang besar bagi peradaban dan ilmu pengetahuan dunia. Namun di sisi lain, umat Islam harus menghadapi sebuah fakta bahwa pendidikan Islam tidak berdaya dihadapkan pada realitas masyarakat industri. $^{25}$

Kenyataan di atas kiranya dapat dihubungkan dengan pendidikan agama Islam yang selama ini lebih menekankan pada hubungan formalitas antara hamba dan Tuhannya. Pada waktu yang bersamaan, Islam diajarkan lebih pada tingkat hafalan, padahal Islam penuh dengan nilai-nilai yang harus dipraktikkan.

Memenuhi kepentingan ini, pendidikan Islam harus mampu mengakses perubahan sosial yang terjadi di masyarakat. Pendidikan Islam tidak boleh mengasingkan diri dari realitas kehidupan sosial yang senantiasa berkembang dan terus berubah mengikuti irama perkembangan peradaban manusia. Dalam kerangka ini dituntut adanya strategi kontekstualisasi pendidikan Islam yang kompetitif, terutama dalam aspek pengelolaan pendidikan Islam. Strategi ini mutlak adanya agar pendidikan Islam tidak terlibas oleh hegemoni perubahan itu sendiri. ${ }^{26}$

Masyarakat kita saat ini sudah modern dan maju dalam banyak segi kehidupan terutama sosial budaya. Saat ini, tolok ukur masyarakat dalam memandang nilai-nilai budaya sudah semakin jelas dan mengerucut pada pemenuhan kebutuhan material semata yang dalam hal ini diwakili oleh atau atas nama kepentingan ekonomi. Padahal, sejujurnya dan yang selalu kita dengung-dengungkan bahwa bangsa kita adalah bangsa yang bermoral, beradab, dan berbudaya, atau lebih tegasnya bangsa yang religius. Ini tampak jelas pada sila pertama dan kedua dalam Pancasila yang merupakan dasar negara ini. 
Lembaga pendidikan Islam yang mengedepankan moralitas dan nilai-nilai keagamaan sebagai basis konsentrasi pengembangan pendidikannya masih dipandang sebelah mata oleh kebanyakan masyarakat kita. Mereka lebih memilih untuk menyekolahkan putra-putri mereka di sekolah umum yang dianggap lebih jelas dan lebih terarah tujuan pendidikannya dan lebih menjanjikan pekerjaan yang layak

Menghadapi era globalisasi dan informasi, peran lembaga pendidikan Islam perlu ditingkatkan. Tuntutan globalisasi tidak mungkin dihindari. Salah satu langkah bijak, kalau tidak mau dalam persaingan, adalah mempersiapkan lembaga pendidikan Islam agar tidak ketinggalan kereta. ${ }^{27}$

Pemenuhan peran edukatifnya dalam penyediaan sumber daya manusia yang berkualitas, lembaga pendidikan Islam harus meningkatkan mutu pendidikannya. Penyediaan sumber daya manusia yang memiliki kompetensi integratif, baik dalam penguasaan pengetahuan agama dan pengetahuan umum maupun kecakapan teknologis serta penyediaan sarana dan prasarana pendidikan, merupakan prasyarat yang tidak bisa diabaikan untuk konteks perubahan sosial akibat globalisasi dan modernisasi.

Manusia yang berhasil di masa depan adalah manusia yang mampu mengembangkan dirinya sehingga ia mampu melakukan inovasi dan improvisasi dalam menghadapi situasi baru yang belum pernah dialaminya. Oleh karena itu, peserta didik perlu dibekali dengan kemampuan intelektual, sosial, dan profesional yang tinggi. Pilar utama pendidikan yang harus ditularkan adalah learning to know, learning to do, learning to be. Aktualisasi tiga element ini merefleksikan agar terjadi keseimbangan antara teori dan praktik sehingga keluaran (output) yang dihasilkan memiliki kecakapan dan kemampuan yang multiguna, baik terhadap agama maupun esensinya sebagai makhluk sosial.

Mempertahankan eksistensi nilai-nilai yang dianut sebelumnya, pendidikan Islam sebagai dasar ideal dan frame harus bisa menyingkronkan perubahan dengan autentitas nilai-nilai islamiyah serta melakukan berbagai pembenahan sistem dan manejemen pendidikan Islam secara sruktural, prosedural, dan progresif terhadap perkembangan zaman di masa yang akan datang.

\section{PENUTUP}

Uraian di atas mengenai tantangan lembaga pendidikan Islam sebagai benteng pertahanan moral bangsa menyimpulkan sebagai berikut:

1. Secara umum terdapat tiga lembaga pendidikan Islam di Indonesia yaitu, pesantren, madrasah, dan perguruan tinggi Islam. Ketiga lembaga pendidikan Islam tersebut yang selama ini memilki peran yang signifikan dalam menghasilkan alumni yang berilmu dan bermoral.

2. Sebagai lembaga pendidikan Islam, pesantren, madrasah, dan perguruan tinggi Islam dimaksudkan untuk mempertahankan nilai-nilai keislaman dengan titik berat pada pendidikan. Lembaga pendidikan Islam tersebut berusaha mendidik anak-anak bangsa ini dengan harapan dapat menjadi orang- 
orang yang beilmu dan bermoral, sehingga menjadi benteng pertahanan moral bangsa dari berbagai tantangan globalisasi dan arus informasi. Lembaga pendidikan Islam ikut terlibat dalam upaya mencerdaskan kehidupan bangsa, tidak hanya dari segi moril, namun telah pula ikut serta memberikan sumbangsih yang cukup signifikan dalam penyelenggaraan pendidikan. Lembaga pendidikan Islam dinilai memiliki kelebihan karena menerapkan pendidikan agama dan umum serta sistem pendidikannya didedikasikan untuk membentuk karakter bangsa.

3. Tantangan lembaga pendidikan Islam adalah perubahan orientasi. Image yang ada tentang lembaga pendidikan Islam cenderung mengarah ke sesuatu yang bersifat agamis saja, berbeda dengan lembaga pendidikan umum yang masyhur dengan sainsnya. Semua itu dirubah dengan tetap mempertahankan dasar lembaga pendidikan Islam sebagai wadah pendidikan yang bersifat agamis, tanpa mengenyampingkan ilmu pengetahuan umum atau dalam hal ini sains dan keterampilan.

\section{CATATAN AKHIR:}

1. Deliar Noer, Gerakan Modern Islam di Indonesia 1990-1942, cet. VI; Jakarta: LP3ES, 1994, h. xi.

2. Zamakhsyari Dhofier, Tradisi Pesantren, Studi tentang Pandangan Hidup Kiai, Jakarta: LP3ES, 1990), h. 18. Lihat juga Dewan Redaksi Ensiklopedi Islam, Ensiklopedi Islam, Jilid 4, cet. III; Jakarta: Ikhtiar Baru Van Hoeve, 1994, h. 91.

3. Abuddin Nata, Sejarah Pertumbuhan dan Perkembangan Lembaga-lembaga Pendidikan Islam di Indonesia, Jakarta: Gramedia, 2001, h. 89.

4. Ibid., h. 91.

5. Nurcholish Madjid, Bilik-bilik Pesantren: Sebuah Potret Perjalanan, Jakarta: Paramadina, 1997, h. 34 .

6. Abdurrahman Mas'ud, "Sejarah dan Budaya Pesantren", dalam Ismail S.M. (Ed.), Dinamika Pesantren dan Madrasah, Yogyakarta: Pustaka Pelajar, 2002, h. 26.

7. Mastuki, Intelektualisme Pesantren: Potret Tokoh dan Cakrawala Pemikiran di Era Perkembangan Pesantren, Jakarta: Diva Pustaka, 2003, h. 2.

8. Faisal Ismail, Paradigma Kebudayaan Islam: Studi Kritis dan Analisis Historis, Jakarta: Projek Peningkatan Kerukunan Hidup Umat Beragama, 2004, h. 99.

9. Atabik Ali dan Ahmad Zuhdi Muhtar, Kamus al-Ashri Arab Indonesia, Yogyakarta: Ma'had Krapyak, 2000, h. 586.

10. Ridwan Nasir, Mencari Tipologi Format Pendidikan Ideal, Yogyakarta:Pustaka Pelajar, 2005, h. 90 .

11. Abuddin Nata, op. cit., h. 196.

12. Lihat Azyumardi Azra, Esei-Esei Intelektual Muslim dan Pendidikan Islam, Jakarta: Logos Wacana Ilmu, 1998, h. 124. Lihat juga Musyrifah Sunanto, Sejarah Peradaban Islam Indonesia, Jakarta: Raja Grafindo Persada, 2007, h. 314-315.

13. Azyumardi Azra, "Upaya Menjawab Tantangan Zaman", dalam rubrik Dialog PERTA Jurnal Komunkasi Perguruan Tinggi Islam, Volume IV No. 01/2001, h.75-77.

14. Azyumardi Azra, "IAIN di Tengah Paradigma Baru Perguruan Tinggi", dalam OASIS Jurnal Pascasarjana STAIN Cirebon, Volume 1 No. 2 Juli-Desember 2008, Cirebon: Program Pascasarjana, 2008, h. 240. 
15. Azyumardi Azra, “Upaya Menjawab Tantangan Zaman", op. cit., h. 77.

16. Husni Rahim, Arah Baru Pendidikan Islam di Indonesia, Jakarta: Logos Wacana Ilmu, 2001, h. 145.

17. Husni Rahim, op. cit., h. 145.

18. Ibid.

19. Ibid.

20. Ibid.

21. Azyumardi Azra, Upaya Menjawab Tantangan Zaman, op. cit., h. 89.

22. Abuddin Nata, Sejarah Pertumbuhan dan Perkembangan Lembaga-lembaga Pendidikan Islam di Indonesia, h. 151.

23. Husni Rahim, op. cit., h. 78.

24. Barizi, (Ed.), Holistika Pemikiran Pendidikan A. Malik Fadjar, Jakarta: Rajawali-UIN Malang, 2005, h.ix.

25. Ahmad Tafsir, "Pemikiran di Zaman Modern" dalam Ensiklopedi Tematis Dunia Islam: Pemikiran dan Peradaban, ed.Taufik Abdullah, et.al., Jilid IV, Jakarta: PT Ichtiar Baru Van Hoeve, t.th., h. 397-398.

26. Husni Rahim, op. cit., 160.

27. Ibid.

\section{DAFTAR PUSTAKA}

Ali, Atabik dan Ahmad Zuhdi Muhtar. Kamus al-Ashri Arab Indonesia. Yogyakarta: Ma'had Krapyak, 2000.

Azra, Azyumardi. Esei-esei Intelektual Muslim dan Pendidikan Islam. Jakarta: Logos, 1999.

------. “Upaya Menjawab Tantangan Zaman”, dalam rubrik Dialog PERTA Jurnal Komunkasi Perguruan Tinggi Islam, Volume IV No. 01/2001.

------. "IAIN di Tengah Paradigma Baru Perguruan Tinggi" dalam OASIS Jurnal Pascasarjana STAIN Cirebon, Volume 1 No. 2 Juli-Desember 2008 (Cirebon: Program Pascasarjana, 2008.

Barizi (Ed.). Holistika Pemikiran Pendidikan A. Malik Fadjar. Jakarta: Rajawali-UIN Malang, 2005.

Dewan Redaksi Ensiklopedi Islam. Ensiklopedi Islam. Jilid 4. Cet. III; Jakarta: Ikhtiar Baru Van Hoeve, 1994.

Dhofier, Zamakhsyari. Tradisi Pesantren, Studi tentang Pandangan Hidup Kiai. Jakarta: LP3ES, 1990.

Ismail, Faisal. Paradigma Kebudayaan Islam: Studi Kritis dan Analisis Historis. Jakarta: Projek Peningkatan Kerukunan Hidup Umat Beragama, 2004.

Madjid, Nurcholish. Bilik-bilik Pesantren: Sebuah Potret Perjalanan. Jakarta: Paramadina, 1997.

Mas'ud, Abdurrahman. "Sejarah dan Budaya Pesantren" dalam Ismail S.M. (Ed.), Dinamika Pesantren dan Madrasah. Yogyakarta: Pustaka Pelajar, 2002.

Mastuki, Intelektualisme Pesantren: Potret Tokoh dan Cakrawala Pemikiran di Era Perkembangan Pesantren. Jakarta: Diva Pustaka, 2003.

Nata, Abuddin. Sejarah Pertumbuhan dan Perkembangan Lembaga-lembaga Pendidikan Islam di Indonesia. Jakarta: Gramedia, 2001.

Nasir, Ridwan. Mencari Tipologi Format Pendidikan Ideal. Cet. I; Yogyakarta:Pustaka 
Pelajar, 2005.

Noer, Deliar. Gerakan Modern Islam di Indonesia 1990-1942. Cet. VI; Jakarta: LP3ES, 1994.

Rahim, Husni. Arah Baru Pendidikan Islam di Indonesia. Jakarta: Logos Wacana Ilmu, 2001.

Shihab, M. Quraish. Membumikan al-Qur'an Fungsi dan Peran Wahyu dalam Kehidupan Masyarakat. Cet. XV; Bandung: Mizan, 1997.

Sunanto, Musyrifah. Sejarah Peradaban Islam Indonesia. Jakarta: Raja Grafindo Persada, 2007

Tafsir, Ahmad. "Pemikiran di Zaman Modern" dalam Ensiklopedi Tematis Dunia Islam: Pemikiran dan Peradaban. Editor Taufik Abdullah, et.al., Jilid IV. Jakarta: PT Ichtiar Baru Van Hoeve, t.th. 